Review

\title{
Canine Myocytes Represent a Good Model for Human Ventricular Cells Regarding Their Electrophysiological Properties
}

\author{
Péter P. Nánási 1,2,*, Balázs Horváth 1,3® ${ }^{1}$, Fábián Tar ${ }^{1}$, János Almássy ${ }^{1}$, Norbert Szentandrássy ${ }^{1,4}$, Norbert Jost ${ }^{5,6}$, \\ István Baczkó ${ }^{5,7} \mathbb{1}$, Tamás Bányász ${ }^{1}$ and András Varró ${ }^{5,6,7}$ \\ 1 Department of Physiology, Faculty of Medicine, University of Debrecen, 4032 Debrecen, Hungary; \\ horvath.balazs@med.unideb.hu (B.H.); tar.fabian@dental.unideb.hu (F.T.); \\ almassy.janos@med.unideb.hu (J.A.); szentandrassy.norbert@med.unideb.hu (N.S.); \\ banyasz.tamas@med.unideb.hu (T.B.) \\ 2 Department of Dental Physiology and Pharmacology, Faculty of Dentistry, University of Debrecen, \\ 4032 Debrecen, Hungary \\ 3 Faculty of Pharmacy, University of Debrecen, 4032 Debrecen, Hungary \\ 4 Department of Basic Medical Sciences, Faculty of Dentistry, University of Debrecen, 4032 Debrecen, Hungary \\ 5 Department of Pharmacology and Pharmacotherapy, Faculty of Medicine, University of Szeged, \\ 6725 Szeged, Hungary; jost.norbert@med.u-szeged.hu (N.J.); baczko.istvan@med.u-szeged.hu (I.B.); \\ varro.andras@med.u-szeged.hu (A.V.) \\ 6 ELKH-SZTE Research Group for Cardiovascular Pharmacology, Eötvös Loránd Research Network, \\ 6725 Szeged, Hungary \\ 7 Department of Pharmacology and Pharmacotherapy, Interdisciplinary Excellence Centre, \\ University of Szeged, 6725 Szeged, Hungary \\ Correspondence: nanasi.peter@med.unideb.hu; Tel.: +36-52255575; Fax: +36-52255116
}

Citation: Nánási, P.P.; Horváth, B.; Tar, F.; Almássy, J.; Szentandrássy, N.; Jost, N.; Baczkó, I.; Bányász, T.; Varró, A. Canine Myocytes Represent a Good Model for Human Ventricular Cells Regarding Their Electrophysiological Properties. Pharmaceuticals 2021, 14, 748. https:// doi.org/10.3390/ph14080748

Academic Editor: Gary J. Stephens

Received: 31 May 2021

Accepted: 20 July 2021

Published: 29 July 2021

Publisher's Note: MDPI stays neutral with regard to jurisdictional claims in published maps and institutional affiliations.

\begin{abstract}
Due to the limited availability of healthy human ventricular tissues, the most suitable animal model has to be applied for electrophysiological and pharmacological studies. This can be best identified by studying the properties of ion currents shaping the action potential in the frequently used laboratory animals, such as dogs, rabbits, guinea pigs, or rats, and comparing them to those of human cardiomyocytes. The authors of this article with the experience of three decades of electrophysiological studies, performed in mammalian and human ventricular tissues and isolated cardiomyocytes, summarize their results obtained regarding the major canine and human cardiac ion currents. Accordingly, L-type $\mathrm{Ca}^{2+}$ current $\left(\mathrm{I}_{\mathrm{Ca}}\right)$, late $\mathrm{Na}^{+}$current $\left(\mathrm{I}_{\mathrm{Na}-\text { late }}\right)$, rapid and slow components of the delayed rectifier $\mathrm{K}^{+}$current $\left(\mathrm{I}_{\mathrm{Kr}}\right.$ and $\mathrm{I}_{\mathrm{Ks}}$, respectively), inward rectifier $\mathrm{K}^{+}$current $\left(\mathrm{I}_{\mathrm{K} 1}\right)$, transient outward $\mathrm{K}^{+}$current $\left(\mathrm{I}_{\mathrm{to} 1}\right)$, and $\mathrm{Na}^{+} / \mathrm{Ca}^{2+}$ exchange current $\left(\mathrm{I}_{\mathrm{NCX}}\right)$ were characterized and compared. Importantly, many of these measurements were performed using the action potential voltage clamp technique allowing for visualization of the actual current profiles flowing during the ventricular action potential. Densities and shapes of these ion currents, as well as the action potential configuration, were similar in human and canine ventricular cells, except for the density of $\mathrm{I}_{\mathrm{K} 1}$ and the recovery kinetics of $\mathrm{I}_{\mathrm{to}}$. $\mathrm{I}_{\mathrm{K} 1}$ displayed a largely four-fold larger density in canine than human myocytes, and $\mathrm{I}_{\text {to }}$ recovery from inactivation displayed a somewhat different time course in the two species. On the basis of these results, it is concluded that canine ventricular cells represent a reasonably good model for human myocytes for electrophysiological studies, however, it must be borne in mind that due to their stronger $\mathrm{I}_{\mathrm{K} 1}$, the repolarization reserve is more pronounced in canine cells, and moderate differences in the frequency-dependent repolarization patterns can also be anticipated.
\end{abstract}

Keywords: cardiac ion currents; human ventricular cells; canine myocytes; action potential configuration; action potential voltage clamp 


\section{Introduction}

In order to better understand the electrophysiology and pathology of the human heart, as well as for the development of new cardioactive agents, reasonably good experimental models of human ventricular cells are needed. In absence of such models, it is difficult to properly interpret the cellular cardiac electrophysiological effects of drugs. Moreover, due to the paucity of proper experimental results, the available in silico human ventricular action potential models [1-5] may still suffer from serious shortcomings. This is basically due to the very limited availability of undiseased human ventricular tissue. Since the early nineties, when the first results on successful isolation of adult human ventricular myocytes were reported [6-8], the cells were digested from small tissue chunks excised from the explanted recipient diseased hearts. Accordingly, these studies were performed using the chunk method for cell isolation, but this technique produced a low yield with many injured cells. Human cardiomyocytes can also be derived from pluripotent stem cells [9], but these myocytes carry several features of immature fetal cardiomyocytes, differing markedly from healthy adult ventricular cells in their electrophysiological properties [10-12].

An alternative approach is to find the best animal model-possibly among the widely available laboratory animals. However, due to the widespread interspecies differences in the electrophysiological properties of these hearts [13-18], a detailed and complex analysis is necessary in this case. Therefore, based dominantly on our earlier experimental results on undiseased human ventricular tissue (obtained by Varró et al. from unused donor hearts after removal of the cuspid valves) using the action potential voltage clamp technique, the profiles of the major human cardiac ion currents ( $\mathrm{I}_{\mathrm{Ca}}, \mathrm{I}_{\mathrm{Na}-l a t e}, \mathrm{I}_{\mathrm{Kr}}, \mathrm{I}_{\mathrm{Ks}}, \mathrm{I}_{\mathrm{K} 1}, \mathrm{I}_{\mathrm{to} 1}, \mathrm{I}_{\mathrm{NCX}}$ ) are summarized in the present article. These results are compared to those obtained from similar cells of dogs since the electrophysiological properties of several ventricular ion currents in the two species seem to be similar regarding both their shape and size [17,19-25]. In addition, the most important interspecies differences observed between ventricular cells of different origins (including human, canine, rabbit, guinea pig, or rat) are also reviewed.

\section{Significance of the Action Potential Voltage Clamp Technique}

The morphology of the cardiac action potential is determined by the finely tuned balance of sequentially activating inward and outward ion currents (for a recent review, see Varró et al. [26]). The amplitude of current at any time depends on the electrochemical gradient (a driving force acting on the ion) and the conductance of the ion channel, governed by its time- and voltage-dependent gating kinetics. Since the membrane potential is continuously changing during the time course of the action potential, the driving force also changes concomitantly. In addition, channel gating has also been shown to be influenced by the dynamics of the membrane potential change (i.e., by the shape of the action potential plateau) [27].

To visualize the actual current profiles conducted during a cardiac action potential, the action potential voltage clamp technique (first applied by Fischmeister et al. in 1984 [28]) was introduced. This technique is essentially based on pharmacological current dissection using the action potential waveform of the cell as a command signal [29]. To date, the action potential voltage clamp method has been successfully applied in a variety of mammalian cardiac cells, including rat [16], porcine [30,31], rabbit [16,30,32-34], guinea pig [35-41], canine $[17,23,24,42,43]$, and human [18-22] myocytes.

\section{Interspecies Differences in Action Potential Morphology and the Underlying Ion Currents}

At first glance, there are no striking differences in the morphology of action potentials in recordings taken from multicellular mammalian ventricular preparations-except for small rodents, like mice or rats (Figure 1A). In these latter species, $\mathrm{I}_{\mathrm{to} 1}, \mathrm{I}_{\mathrm{Kur}}$, and $\mathrm{I}_{\mathrm{K} 1}$ are very pronounced, while $\mathrm{I}_{\mathrm{Ca}}$ inactivates rapidly [44-47]. As a consequence, there is no room for plateau formation, therefore, action potential duration is extremely short. Furthermore, there is a reverse and slightly biphasic relationship between action potential 
duration and the pacing cycle length (Figure 1B), in addition to the negative force-frequency relationship, a characteristic of these species. Both are the opposite of those observed in humans, dogs, or guinea pigs, reflecting robust differences in intracellular $\mathrm{Ca}^{2+}$ handling. Consequently, electrophysiological results obtained in rat or murine myocytes are often difficult to extrapolate to humans.

In rabbit myocytes, $\mathrm{I}_{\mathrm{to} 1}$ is expressed in epicardial but not in endocardial myocytes [48-50]. This $\mathrm{I}_{\text {to1 }}$, mediated dominantly by $\mathrm{Kv} 1.4 \alpha$ channel subunits, is markedly different from canine and human $\mathrm{I}_{\text {to1 }}$, which is largely mediated by the robustly expressed $\mathrm{Kv} 4.3$ subunits [51-53] with only relatively minor Kv1.4 contribution [52,54]. Importantly, the recovery kinetics of the rabbit type $\mathrm{I}_{\mathrm{to} 1}$ is much slower than the canine and human type, resulting in an inverse or biphasic cycle length-APD relationship, as shown in Figure 1B (see also [55-57]). Furthermore, in rabbits, both $\mathrm{I}_{\mathrm{Ca}}$ and $\mathrm{I}_{\mathrm{Na} \text {-late }}$ display a saddle-like profile under action potential voltage clamp conditions $[16,17]$ in contrast to dogs and humans $[17,22,24]$. In summary, the ion currents in rabbit ventricular cells and the frequency-dependent behavior of the rabbit ventricular action potential are markedly different from those observed in humans.
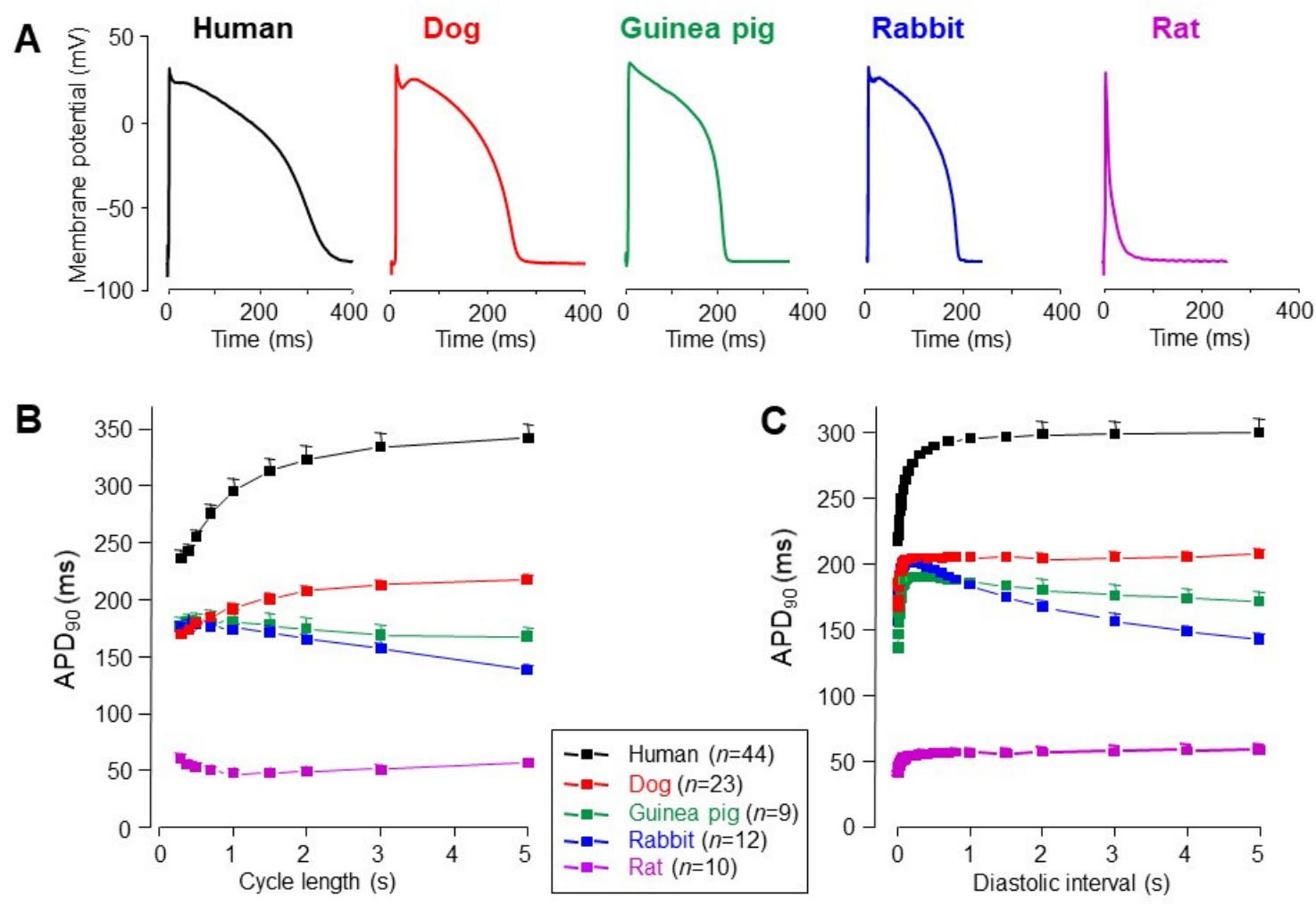

Figure 1. Action potential configurations (A), steady-state rate-dependent action potential durations at $90 \%$ of repolarization $\left(\mathrm{APD}_{90},(\mathbf{B})\right)$, and $\mathrm{APD}_{90}$ restitution relations $(\mathbf{C})$ measured in multicellular human, canine, guinea pig, rabbit, and rat ventricular preparations using sharp $3 \mathrm{M} \mathrm{KCl-filled} \mathrm{microelectrodes.} \mathrm{The} \mathrm{restitution} \mathrm{curves} \mathrm{were} \mathrm{obtained} \mathrm{by} \mathrm{gradually}$ increasing the diastolic interval following a train of action potential stimulated at a stable cycle length. Symbols and bars are mean \pm SEM values; $(n)$ denotes the number of preparations studied [57].

Electrophysiological properties of guinea pig ventricular myocytes are also distinctly different from those of canine and human cells. Guinea pig action potentials do not display phase-1 repolarization (Figure 1A). This is because of the lack of $\mathrm{I}_{\mathrm{to} 1}$ in the guinea pig ventricle $[13,58]$ and results in a ramp-like plateau phase. From this point of view, guinea pig cells are different from most mammalian species, including dogs and humans [42,59]. Instead of $\mathrm{I}_{\mathrm{to} 1}$, there is a robust $\mathrm{I}_{\mathrm{Ks}}$ in the guinea pig ventricle, which is more pronounced than the same current in human or dog $[21,60]$. Similar to rabbits, $\mathrm{I}_{\mathrm{Ca}}$ and $\mathrm{I}_{\mathrm{Na}}$-late display a saddle-like profile in guinea pigs under action potential voltage clamp conditions $[17,18]$ 
in sharp contrast to dogs and humans $[17,22,24]$. Considering these properties, guinea pig myocytes do not seem to be fairly good models of human ventricular cells.

Pigs are not considered conventionally "laboratory animals", however, the swine heart is potentially suitable for cardiac transplantation following appropriate immunological modification due to its favorable anatomical properties [61]. Therefore, our analysis would not be complete without discussing the electrophysiological properties of porcine ventricular myocytes. Studying the transmural heterogeneity of action potential morphology, no regional differences were found [62]. Others have identified $M$ cells in the deep regions [63], while others reported transmural inhomogeneity without the identification of $\mathrm{M}$ cells [64]. Although the spike-and-dome configuration of the porcine ventricular action potential is similarly shaped to that observed in canine and human myocytes, the pronounced phase-1 repolarization of the porcine action potential is related to the high amplitude of $\mathrm{I}_{\mathrm{to}}$, identified as a Ca ${ }^{2+}$-sensitive $\mathrm{Cl}^{-}$current [62]. In contrast to human [65] and canine [66] $\mathrm{I}_{\mathrm{to}}$, porcine myocytes do not express Kv4.3 channels, and consequently, $\mathrm{I}_{\mathrm{to1}}$ is absent in these cells [62]. L-type $\mathrm{Ca}^{2+}$ current seems relatively weak in porcine myocytes, since the density of 3.6 A/F, measured in porcine myocytes at $+10 \mathrm{mV}$ [67], is significantly less than observed by us in humans or canine cells at the same test potential (see Figure 2C). There are only two reports in the literature presenting action potential voltage clamp experiments in swine ventricular cells $[30,31]$. Comparing these to the respective canine and human data [21,65], it can be concluded that the intensity of $\mathrm{I}_{\mathrm{Ks}}$ is similar, while densities and integrals of $\mathrm{I}_{\mathrm{K} 1}$ and $\mathrm{I}_{\mathrm{Kr}}$ are significantly higher in pigs than in dogs or humans. An additional difference between porcine and canine/human myocytes is in the shape of $\mathrm{I}_{\mathrm{Na}-\text { late, }}$, since human and canine cells display $\mathrm{I}_{\mathrm{Na}-\text { late }}$ with monotonically decreasing amplitude ("decrescendo" profile), while the shape of porcine $\mathrm{I}_{\mathrm{Na} \text {-late }}$ is saddle-like, showing a "crescendo" profile similar to rabbit and guinea pig $\mathrm{I}_{\mathrm{Na}-\text { late }}$ [17]. These characteristic differences and similarities between human, canine, and porcine myocytes are summarized in the supplement. Although porcine myocytes share several electrophysiological properties with human ventricular cells, the similarity between human and canine cells is superior compared to the same relation between human and porcine myocytes (Table S1, Supplementary Materials).

Although it is not evident from Figure 1, it must be noted that there is a striking difference between the heart rate of all rodents used in the laboratory versus human, canine and porcine hearts. The baseline heart rate in each rodent is much higher than that of larger mammals including humans, pigs, and dogs, which in turn, do not markedly differ from one another in this regard. This is important considering the voltage-, time-, and consequently, rate-dependent gating kinetics of cardiac ion channels. 
A
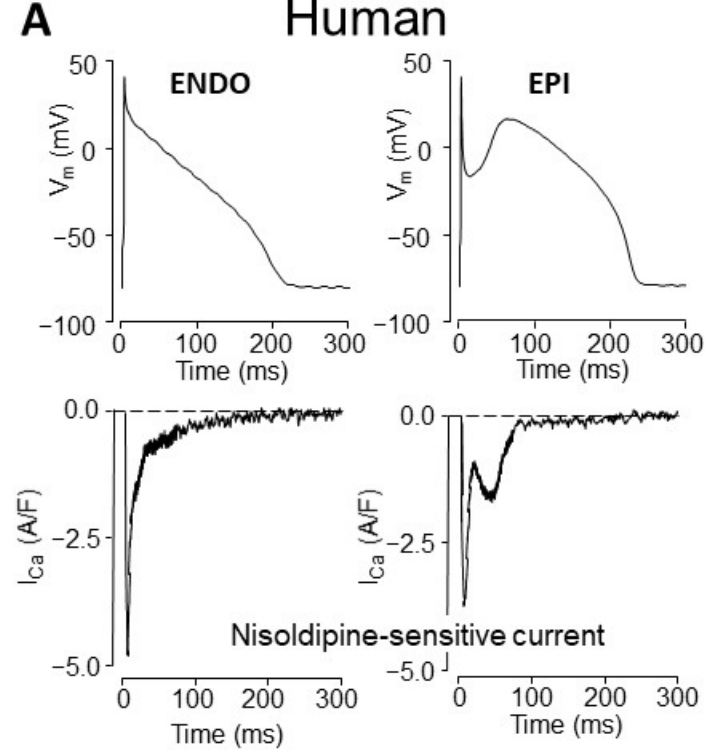

B

B Dog
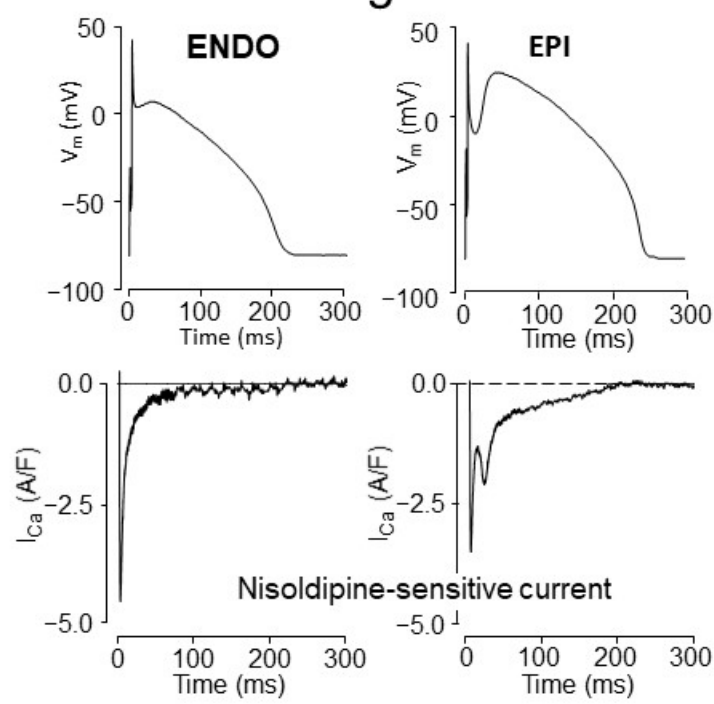

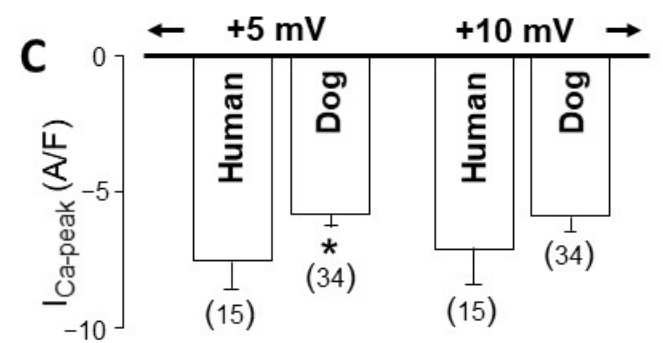

Figure 2. L-type $\mathrm{Ca}^{2+}$ currents in human (A) and canine (B) ventricular myocytes of epicardial (EPI) and endocardial (ENDO) origin. Command action potentials above and $\mathrm{I}_{\mathrm{Ca}}$ recordings below. $\mathrm{I}_{\mathrm{Ca}}$ was excised by $1 \mu \mathrm{M}$ nifedipine. Note the double-peaked $\mathrm{I}_{\mathrm{Ca}}$ records in EPI and the single-peaked ones in ENDO preparations in both species. (C) Comparison of peak current densities between pooled human and canine $\mathrm{I}_{\mathrm{Ca}}$ obtained under conventional voltage clamp conditions. At test potentials of $+5 \mathrm{mV}$ or more negative, significant differences were observed (human $\mathrm{I}_{\mathrm{Ca}}$ was greater), while no significant differences were found at $+10 \mathrm{mV}$ or more positive voltages. Columns and bars are mean $\pm \operatorname{SEM}$ values, $(n)$ denotes the number of myocytes studied, the asterisk $\left({ }^{*}\right)$ indicates significant differences between human and canine $\mathrm{I}_{\mathrm{Ca}}$ data. (Data from references $[21,22,24])$.

\section{Comparison of Human and Canine Ion Currents under Action Potential Voltage Clamp Conditions}

Due to the considerable interspecies differences discussed above, it seems reasonable to focus on canine myocytes and compare their ion currents to those recorded from undiseased human cells under identical experimental conditions, which is the action potential voltage clamp in the majority of experiments presented in this article. In contrast to the subendocardial myocytes, which are the usually impaled cell type in multicellular studies, the target cell can be freely chosen by its origin or action potential morphology when action potentials are recorded from isolated myocytes. This is demonstrated in Figure 3A by comparing the action potential configuration of canine left ventricular myocytes of subepicardial (EPI), subendocardial (ENDO), and midmyocardial (MID) origin. The asymmetrical transmural distribution of $\mathrm{I}_{\text {to1 }}$, which is manifested in the various magnitudes of phase- 1 repolarizations, as shown in Figure 3A, is a common feature of canine and human ventricular myocytes $[59,68-71]$. The density of $\mathrm{I}_{\text {to1 }}$ was reported to be $2-5$-fold greater in EPI than ENDO cells in canine [70,72] and 3-4-fold greater in human $[69,73,74]$ ventricle depending on the experimental conditions, such as the temperature or test potential. When using identical (EPI-like) command action potentials in midmyocardial human and canine myocytes, no significant differences can be observed in the profiles (Figure 3B) or densities of $\mathrm{I}_{\mathrm{to1}}$ (Figure 3C). This apparently contradicts previous results 
obtained under conventional voltage clamp conditions by Akar et al. [52], who pointed out kinetic differences between human and canine $\mathrm{I}_{\mathrm{to} 1}$. Although both human and canine $\mathrm{I}_{\mathrm{to}}$ is conducted mainly by Kv 4.3 channels, the contribution of the Kv1.4 channel was also verified in both canine and human ventricular myocardium [75]. In human ventricular muscle, the majority of the myocytes showed biphasic recovery from inactivation with faster (12.1-13.2 ms) and slower (1197-1283 ms) time constants. These values correspond to the recovery kinetics of $\mathrm{Kv} 4.3$ and Kv1.4 channels, respectively [54]. In addition, the $\mathrm{Kv}$ channel protein distribution patterns showed transmural heterogeneity reflected also in $\mathrm{I}_{\text {to1 }}$ current densities and action potential configurations [75]. In canine ventricular myocytes, $\mathrm{I}_{\text {to }}$ also exhibits biphasic recovery from inactivation but with distinctly different faster (28.4-56.6 ms) and slower (177.5-546.6 ms) time constants [76] than those measured in humans. This slight but significant difference in the recovery kinetics is associated with the different degrees of Kv4.3 and Kv1.4 channel protein expression in the two species [77]. In both humans and dogs, the amplitude of $\mathrm{I}_{\text {to }}$ strongly depends on the level of KChIP2 subunit channel protein expression [77].

It is important to recognize that both in human [54] and dog [78] ventricular muscle, $\mathrm{I}_{\text {to }}$ "window current" was observed, i.e., there is an overlap between the steady-state activation and inactivation curves in the voltage range between -30 and $0 \mathrm{mV}$. Therefore, $\mathrm{I}_{\mathrm{to}}$ can carry small but measurable current during the plateau and early phase 3 repolarization supporting repolarization as part of the repolarization reserve.

Another implication of the EPI-ENDO differences observed in action potential configuration is the differently shaped $\mathrm{I}_{\mathrm{Ca}}$ profiles in myocytes of EPI and ENDO origin recorded under action potential voltage clamp conditions. As demonstrated in Figure 2, in both species (i.e., in humans and dogs), $\mathrm{I}_{\mathrm{Ca}}$ displays a double peak profile in EPI, but not in ENDO cells $[20,24]$. This is the consequence of the different action potential contours since the application of an EPI action potential to an ENDO cell resulted in a double peak-shaped $\mathrm{I}_{\mathrm{Ca}}$ signal [24]. The density of $\mathrm{I}_{\mathrm{Ca}}$ was not significantly different in canine and human myocytes when measured at test potentials more positive to $+5 \mathrm{mV}$ using conventional voltage clamp protocols, however, the density of $\mathrm{I}_{\mathrm{Ca}}$ was moderately but significantly greater in humans than in canine cells at membrane potentials of $+5 \mathrm{mV}$ or more negative values [21].
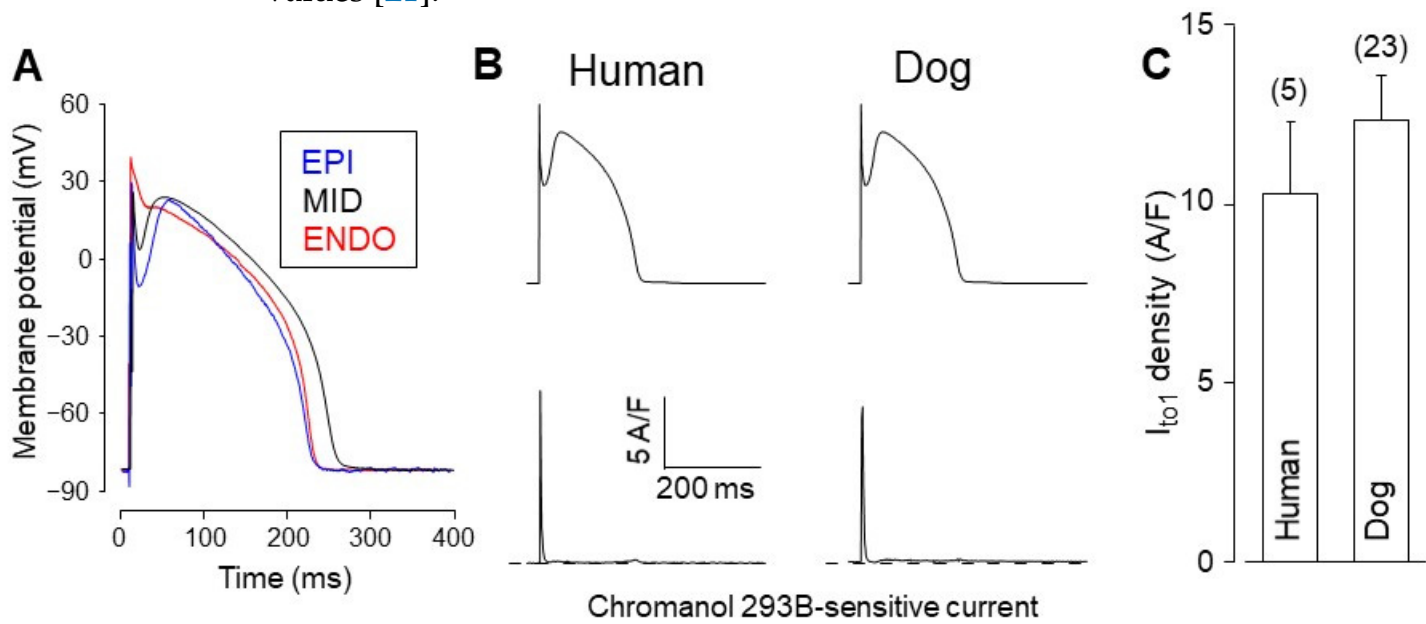

Figure 3. Transient outward $\mathrm{K}^{+}$currents in human and canine left ventricular myocytes. (A) Differences in action potential morphology in canine ventricular cells derived from the subepicardial (EPI), midmyocardial (MID), and subendocardial (ENDO) layers. (B) Command action potentials (top) and transient outward $\mathrm{K}^{+}$current $\left(\mathrm{I}_{\text {to1 }}\right.$ ) records (bottom) taken from midmyocardial human and canine myocytes under action potential voltage clamp conditions. The cycle length of stimulation was $700 \mathrm{~ms}$ in the canine and $1000 \mathrm{~ms}$ in the human cells. (C) Average $\mathrm{I}_{\mathrm{to1}}$ densities. $\mathrm{I}_{\mathrm{to1}}$ was defined as a $100 \mu \mathrm{M}$ chromanol 293B-sensitive current. Columns and bars are mean \pm SEM values, $(n)$ denotes the number of myocytes studied. Unpublished data from Varró et al. 
$\mathrm{I}_{\mathrm{Na}-\text { late, }}$ identified in human ventricular cells as a slowly inactivating component of $\mathrm{I}_{\mathrm{Na}}$ [79], is also very similar in human and canine myocytes compared under either conventional or action potential voltage clamp conditions (Figure $4 \mathrm{~A}, \mathrm{~B}$ ). $\mathrm{I}_{\mathrm{Na} \text {-late }}$ current densities (determined as currents excised by application of $20 \mu \mathrm{M}$ tetrodotoxin) are not significantly different in the two species (Figure 4C). More importantly, the decay time constants obtained for $\mathrm{I}_{\mathrm{Na}-\text { late }}$ were also similar: $67 \pm 5$ and $60 \pm 3 \mathrm{~ms}$, respectively, in contrast to the three-fold longer value of $155 \pm 16 \mathrm{~ms}$ in guinea pig cells [17]. This may explain why $\mathrm{I}_{\mathrm{Na}-\text { late }}$ displays a "decrescendo" profile during the action potential in humans and canines, while a "crescendo" profile in guinea pig myocytes [17].

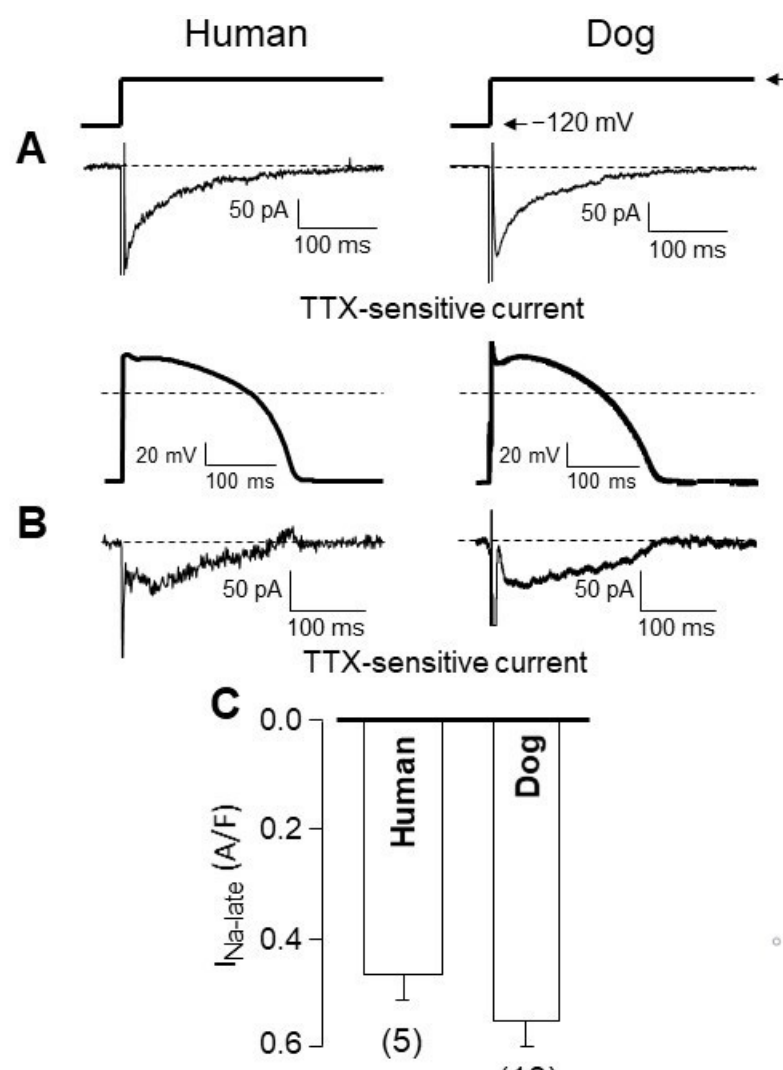

(13)
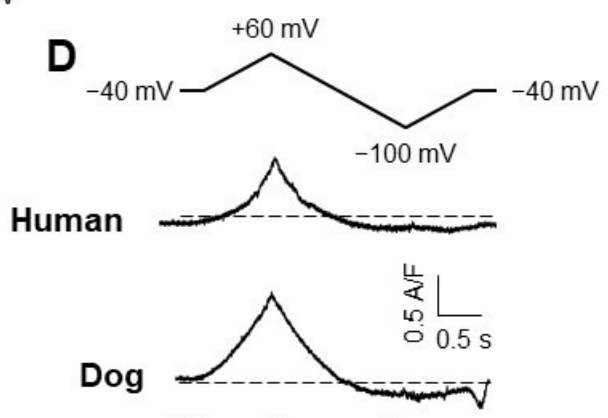

$\mathrm{Ni}^{2+}$-sensitive current

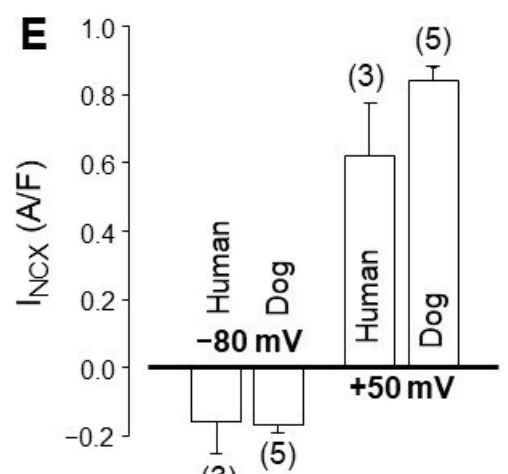

(3)

Figure 4. (A-C) Late $\mathrm{Na}^{+}$current $\left(\mathrm{I}_{\mathrm{Na}-\text { late }}\right)$ in human and canine ventricular myocytes. $\mathrm{I}_{\mathrm{Na}-\text { late }}$ was recorded under conventional voltage clamp (A) and action potential voltage clamp conditions (B). The current in this latter case was excised by $10 \mu \mathrm{M}$ TTX. Pulse protocols are shown above. (C) Peak densities of $\mathrm{I}_{\mathrm{Na} \text {-late }}$ measured with action potential voltage clamp in human and canine myocytes. (D) Representative $\mathrm{I}_{\mathrm{NCX}}$, defined as a $10 \mathrm{mM} \mathrm{Ni}^{2+}$-sensitive current, recorded using a voltage ramp $(-40 \mathrm{mV} \rightarrow+60 \mathrm{mV}->-100 \mathrm{mV}->-40 \mathrm{mV})$. (E) Peak inward (measured at $-80 \mathrm{mV}$ ) and outward (measured at $+50 \mathrm{mV})$ NCX current densities. Columns and bars are mean \pm SEM values, $(n)$ denotes the number of myocytes studied. (Data from references $[17,21]$ ).

The current generated by the $\mathrm{Na}^{+} / \mathrm{Ca}^{2+}$ exchanger is difficult to study under action potential voltage clamp conditions. Therefore, it is usually defined as a $\mathrm{Ni}^{2+}$-sensitive current measured using voltage ramps of outward or inward directions, representing the reverse and forward mode activities of the exchanger, respectively. The profiles (Figure 4D) and densities (Figure $4 \mathrm{E}$ ) of $\mathrm{I}_{\mathrm{NCX}}$ are not significantly different in human and canine myocytes comparing either their inward or outward components [21].

As displayed in Figure 5, the shape and density of $\mathrm{I}_{\mathrm{Kr}}$, defined as an E-4031-sensitive current, as well as the expression of the respective main channel protein, ERG is identical in canine and human ventricular cells. The situation is somewhat different in the case of $\mathrm{I}_{\mathrm{Ks}}$, defined as an L-735,821-sensitive current since its density was lower in humans than in canine cells when measured using conventional voltage clamp, but no difference was 
observed in the two species under action potential voltage clamp conditions (Figure 5B, see also [21]). Interpretation of $I_{K s}$ is further complicated by the asymmetrical expression of the $\mathrm{I}_{\mathrm{Ks}}$ specific channel proteins since KvLQT1 expression is lower while the expression of $\operatorname{minK}$ is higher in canine than in human myocytes (Figure 5C, [21]). Importantly, the amplitude of $\mathrm{I}_{\mathrm{Ks}}$ is similarly small in both canine and human ventricular myocytes under baseline conditions according to the action potential voltage clamp records shown in Figure 5A,B, therefore its contribution to repolarization is negligible under baseline conditions [80,81]. However, its importance is significant following sympathetic stimulation, when the density of $\mathrm{I}_{\mathrm{Ks}}$ robustly increases [82-84]. Similarly, the relative contribution of $\mathrm{I}_{\mathrm{Ks}}$ to repolarization increases in both species in case of malfunction of other repolarizing currents (typically $\mathrm{I}_{\mathrm{Kr}}$ ) resulting in a longer plateau phase allowing more time for additional $\mathrm{I}_{\mathrm{Ks}}$ to develop, thus the compensatory contribution of $\mathrm{I}_{\mathrm{Ks}}$ to the repolarizing reserve can be augmented.

A

Human
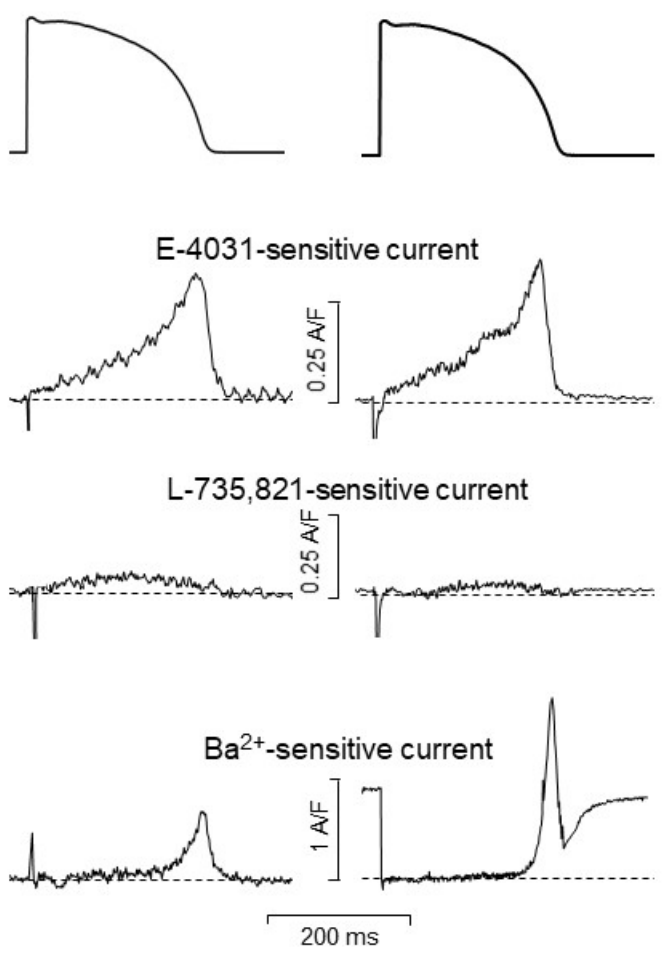

B
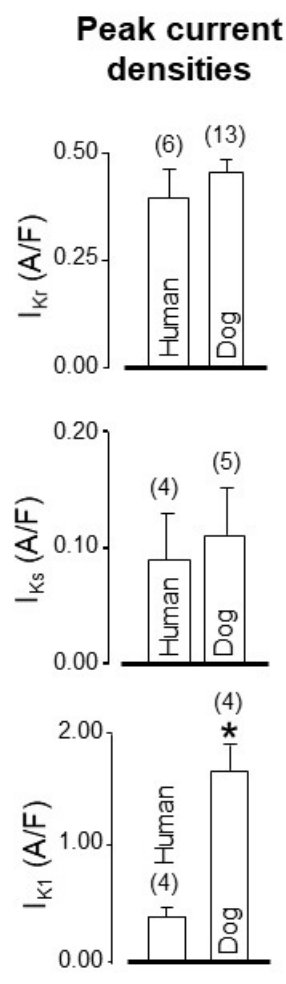

C

\section{Channel protein expression}
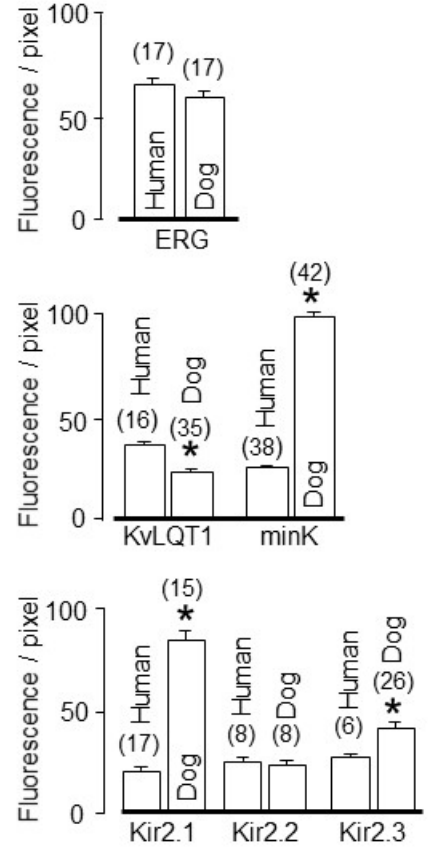

Figure 5. Comparison of peak $\mathrm{I}_{\mathrm{Kr}}, \mathrm{I}_{\mathrm{Ks}}$, and $\mathrm{I}_{\mathrm{K} 1}$ current densities in human and canine ventricular myocytes under action potential voltage clamp conditions $(\mathbf{A}, \mathbf{B}) . \mathrm{I}_{\mathrm{Kr}}, \mathrm{I}_{\mathrm{Ks}}$, and $\mathrm{I}_{\mathrm{K} 1}$ were excised by $5 \mu \mathrm{M}$ E-4031, $0.1 \mu \mathrm{M}$ L-735,821, and 500 $\mu \mathrm{M}$ $\mathrm{BaCl}_{2}$, respectively. (C) Expression of the main channel proteins in human and canine ventricular myocardium. Columns and bars are mean \pm SEM values, $(n)$ denotes the number of myocytes in (B), and myocardial samples in (C), the asterisks $\left({ }^{*}\right)$ indicate significant differences between human and canine data. (Data from reference [21]).

In contrast to $\mathrm{I}_{\mathrm{Kr}}$ and $\mathrm{I}_{\mathrm{Ks}}$, the density of $\mathrm{I}_{\mathrm{K} 1}$ is sharply different in human and canine cells because it is four-fold greater in dogs than in humans (Figure 5A,B and Figure 6B). This is due to the stronger expression of the dominant channel proteins Kir2.1 and Kir2.3 in canine cells (Figure 5C). As a consequence, canine myocytes display a greater repolarization reserve than human cells [21]. This implies that the repolarization lengthening effect of $\mathrm{K}^{+}$channel inhibitor class 3 antiarrhythmic agents is more pronounced in humans than in canine myocytes. This has to be borne in mind when using canine ventricular myocytes to test the repolarization prolonging (side) effect of a new investigational compound for safety pharmacological purposes. As demonstrated in Figure 6, the voltage dependence of 
the two main $\mathrm{K}^{+}$currents $\left(\mathrm{I}_{\mathrm{Kr}}\right.$ and $\mathrm{I}_{\mathrm{K} 1}$ ) governing terminal repolarization is identical and independent of the pacing cycle length in both species [23]. Accordingly, apart from the higher density of the canine than the human $\mathrm{I}_{\mathrm{K} 1}$, the kinetic properties of the two currents are quite similar in dogs and humans.
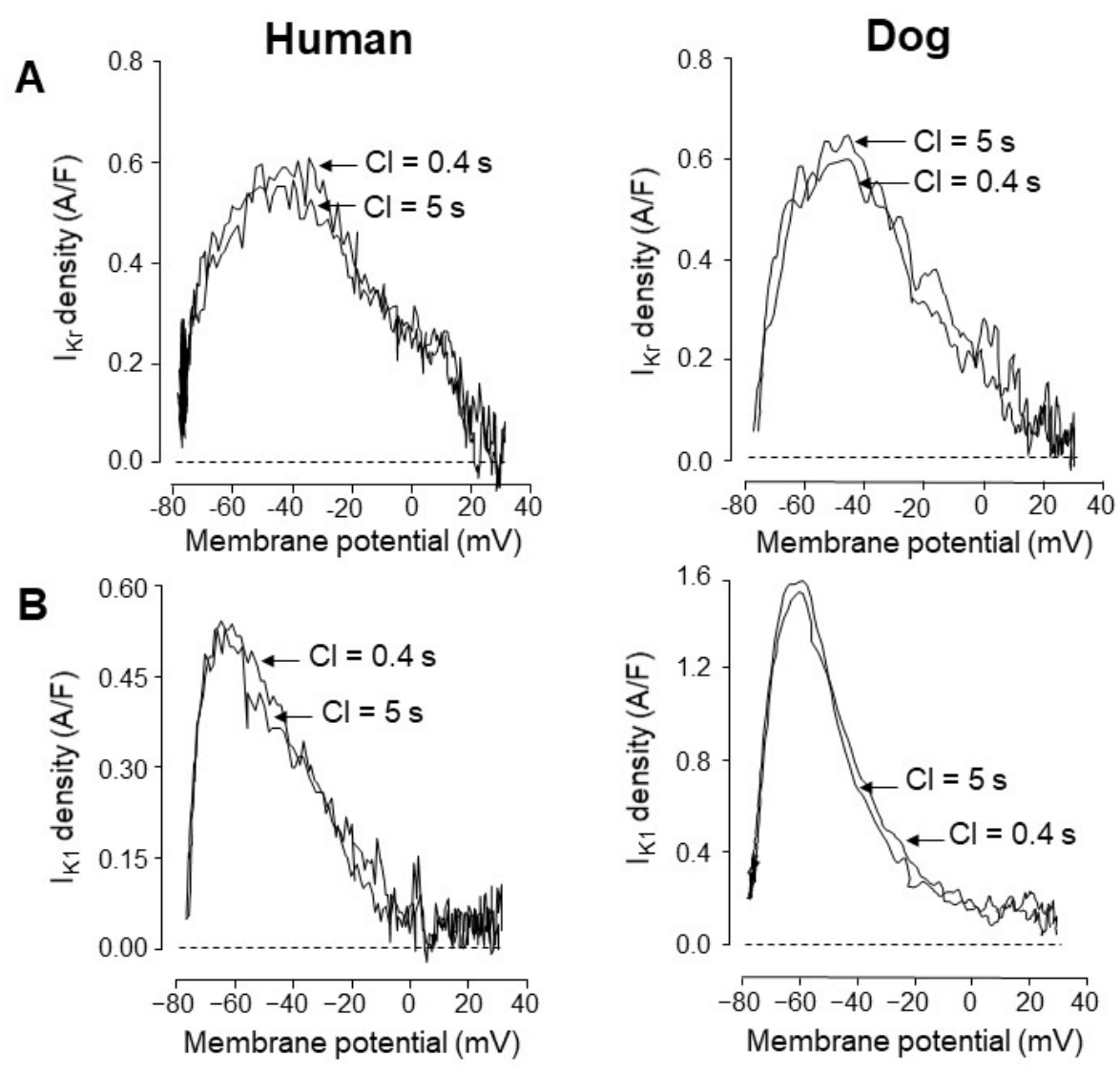

Figure 6. Phase-plane analysis of $\mathrm{I}_{\mathrm{Kr}}$ (excised by $1 \mu \mathrm{M} \mathrm{E}-4031$, (A)) and $\mathrm{I}_{\mathrm{K} 1}$ (excised by $10 \mu \mathrm{M} \mathrm{BaCl}_{2}$, (B)) obtained under action potential voltage clamp conditions in human and canine ventricular myocytes. Representative current-voltage relationships were compared at two different pacing cycle lengths ( 0.4 and $5 \mathrm{~s})$. The currents showed no rate-dependent properties and displayed similar current-voltage relationships in the two species. Note that the peak amplitude of $\mathrm{I}_{\mathrm{Kr}}$ was identical in the canine and human myocytes, while the peak amplitude of $\mathrm{I}_{\mathrm{K} 1}$ was three-fold greater in dogs than in humans. (Data from reference [23]).

Finally, it is worthwhile to compare human and canine ventricular cells in terms of regional differences in the expression of ion channel proteins. In Figure 7, the two cell types are compared in terms of EPI versus MID and also APEX versus BASIS origin. Differences in the expression patterns of $\mathrm{Na}^{+}$(Nav1.5), $\mathrm{Ca}^{2+}(\alpha 1 \mathrm{C})$, and several $\mathrm{K}^{+}$channel-forming proteins (Kir2.1, Kv4.3, Kv1.4, KChiP2, ERG, MiRP1, KvLQT1, and minK) displayed very similar regional differences in human and canine myocytes $[19,20]$. 


\section{Regional differences in expression of channel proteins}
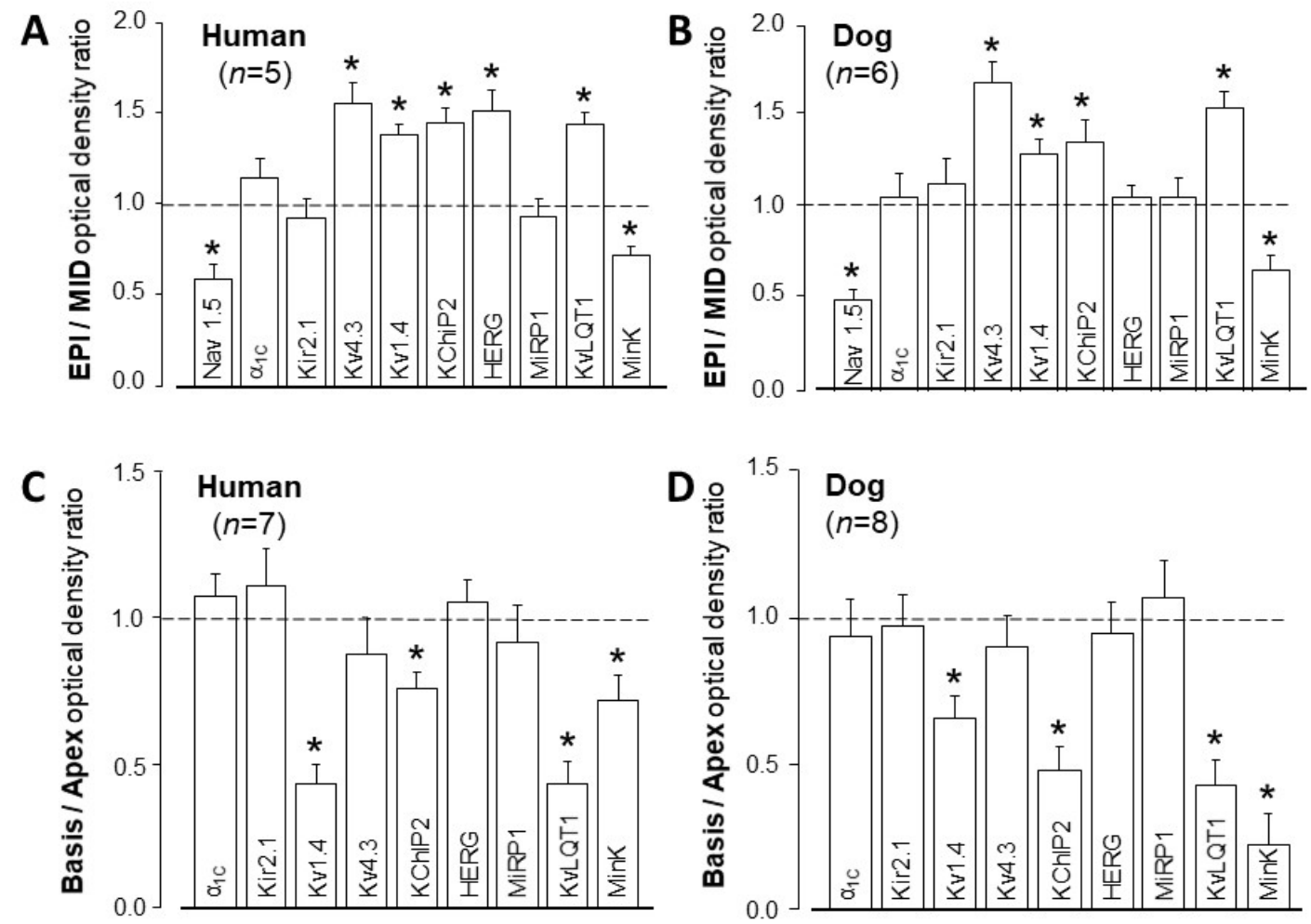

Figure 7. Regional inhomogeneity of the channel protein expression pattern in human and canine ventricular myocardium. (A,B) Epicardial versus midmyocardial distribution. (C,D) Apical versus basal distribution. Columns and bars are mean \pm SEM values, $(n)$ denotes the number of myocardial samples studied, the asterisks $\left({ }^{*}\right)$ indicate significant differences from the ratio of 1 . (Data from references $[19,20]$ ).

\section{Concluding Remarks}

It can be concluded that there is still a severe lack of proper cellular electrophysiological data from undiseased human ventricular tissue. Therefore, further studies are needed in this area to fill this gap, in order to better understand and interpret the translational value of the electrophysiological data obtained in small rodents, guinea pigs, rabbits, and dogs. The available data, however, suggest that-in spite of the modest differences between canine and human ventricular electrophysiology regarding recovery kinetics of $\mathrm{I}_{\text {to1 }}$ and differences in density of $\mathrm{I}_{\mathrm{K} 1}$ - it is evident that dog ventricular preparations offer a translational advantage over those of small rodents, guinea pigs, and rabbits. The significant differences in the translational value of data obtained from different animal models should be kept in mind during physiological, pathophysiological, and pharmacological investigations.

Supplementary Materials: The following are available online at https:/ /www.mdpi.com/article/10 $.3390 /$ ph14080748/s1, Table S1: Comparison of most important electrophysiological properties of human, canine and porcine ventricular cardiomyocytes.

Author Contributions: Conceptualization, P.P.N., A.V.; resources, P.P.N., A.V.; data curation, N.J., I.B., A.V.; writing—original draft preparation, P.P.N., A.V.; writing-review and editing, B.H., T.B., J.A., N.S., N.J., I.B.; visualization, P.P.N., B.H., F.T., A.J., N.S., N.J., I.B., A.V.; supervision, P.P.N., A.V.; project ad-ministration, P.P.N., B.H., N.J., I.B., A.V.; funding acquisition, P.P.N., B.H., I.B., A.V. All authors have read and agreed to the published version of the manuscript.

Funding: This work was funded by the National Research Development and Innovation Fund of Hungary (NKFIH K-119992, NKFIH-PD120794, NKFIH-FK128116, K-135464, K-128851, TKP2020NKA-04), from the Thematic Excellence Programme of the Ministry for Innovation and Technology in Hungary (ED-18-1-2019-0028), and from the Ministry of Human Capacities Hungary (20391- 
3/2018/FEKUSTRAT, GINOP-2.3.2-15-2016-00040). The GINOP and EFOP projects are co-financed by the European Union and the European Regional Development Fund. Further support was obtained by the Hungarian Academy of Sciences (János Bolyai Research Scholarship to B.H.).

Institutional Review Board Statement: Not applicable.

Informed Consent Statement: Not applicable.

Data Availability Statement: Data sharing not applicable.

Conflicts of Interest: The authors declare no conflict of interest.

\section{References}

1. Grandi, E.; Pasqualini, F.S.; Bers, D.M. A novel computational model of the human ventricular action potential and Ca transient. J. Mol. Cell Cardiol. 2010, 48, 112-121. [CrossRef]

2. O'Hara, T.; Virág, L.; Varró, A.; Rudy, Y. Simulation of the undiseased human cardiac ventricular action potential: Model formulation and experimental validation. PLoS Comput Biol. 2011, 7, e1002061. [CrossRef] [PubMed]

3. Pueyo, E.; Dangerfield, C.E.; Britton, O.J.; Virág, L.; Kistamás, K.; Szentandrássy, N.; Jost, N.; Varró, A.; Nánási, P.P.; Burrage, K.; et al. Experimentally-based computational investigation into beat-to-beat variability in ventricular repolarization and its response to ionic current inhibition. PLoS ONE 2016, 11, e0151461. [CrossRef]

4. Tomek, J.; Bueno-Orovio, A.; Passini, E.; Zhou, X.; Minchole, A.; Britton, O.; Bartolucci, C.; Severi, S.; Shrier, A.; Virag, L.; et al. Development, calibration, and validation of a novel human ventricular myocyte model in health, disease, and drug block. $e$ Life 2019, 8, e48890. [CrossRef] [PubMed]

5. Ten Tusscher, K.H.; Noble, D.; Noble, P.J.; Panfilov, A.V. A model for human ventricular tissue. Am. J. Physiol. Heart Circ. Physiol. 2004, 286, H1573-H1589. [CrossRef] [PubMed]

6. Beuckehnann, D.J.; Nabauer, M.; Erdmann, E. Characteristics of calcium-current in isolated human ventricular myocytes from patients with terminal heart failure. J. Mol. Cell Cardiol. 1991, 23, 929-937. [CrossRef]

7. Nánási, P.P.; Varró, A.; Lathrop, D.A. Ionic currents in ventricular myocytes isolated from the heart of a patient with idiopathic cardiomyopathy. Cardioscience 1992, 3, 85-89.

8. Varró, A.; Nánási, P.P.; Lathrop, D.A. Potassium currents in isolated human atrial and ventricular cardiocytes. Acta Physiol. Scand. 1993, 149, 133-142. [CrossRef]

9. Mummery, C.L. Perspectives on the use of human induced pluripotent stem cell-derived cardiomyocytes in biomedical research. Stem Cell Rep. 2018, 11, 1306-1311. [CrossRef]

10. Casini, S.; Verkerk, A.O.; Remme, C.A. Human iPSC-derived cardiomyocytes for investigation of disease mechanisms and therapeutic strategies in inherited arrhythmia syndromes: Strengths and limitations. Cardiovasc. Drugs Ther. 2017, 31, 325-344. [CrossRef]

11. Horváth, A.; Lemoine, M.D.; Löser, A.; Mannhardt, I.; Flenner, F.; Uzun, A.U.; Neuber, C.; Breckwoldt, K.; Hansen, A.; Girdauskas, E.; et al. Low resting membrane potential and low inward rectifier potassium currents are not inherent features of hiPSC-derived cardiomyocytes. Stem Cell Rep. 2018, 10, 822-833. [CrossRef]

12. Verkerk, A.O.; Remme, C.A. 'Mature' resting membrane potentials in human-induced pluripotent stem cell-derived cardiomyocytes: Fact or artefact? Europace 2019, 21, 1928. [CrossRef]

13. Varró, A.; Lathrop, D.A.; Hester, S.B.; Nánási, P.P.; Papp, J.G. Ionic currents and action potentials in rabbit, rat and guinea pig ventricular myocytes. Basic Res. Cardiol. 1993, 88, 93-102. [PubMed]

14. Meyer, R.; Linz, K.W.; Surges, R.; Meinardus, S.; Vees, J.; Hoffmann, A.; Windholz, O.; Grohe, C. Rapid modulation of L-type calcium current by acutely applied oestrogens in isolated cardiac myocytes from human, guinea-pig and rat. Exp. Physiol. 1998, 83, 305-321. [CrossRef]

15. Sham, J.S.; Hatem, S.N.; Morad, M. Species differences in the activity of the $\mathrm{Na}^{+}-\mathrm{Ca}^{2+}$ exchanger in mammalian cardiac myocytes. J. Physiol. 1995, 488, 623-631. [CrossRef] [PubMed]

16. Linz, K.W.; Meyer, R. Profile and kinetics of the L-type calcium current during the cardiac ventricular action potential compared in guinea-pigs, rats and rabbits. Pflügers Arch. 2000, 439, 588-599. [CrossRef]

17. Horváth, B.; Hézső, T.; Szentandrássy, N.; Kistamás, K.; árpádffy-Lovas, T.; Varga, R.; Gazdag, P.; Veress, R.; Dienes, C.; Baranyai, D.; et al. Late sodium current in human, canine and guinea pig ventricular myocardium. J. Mol. Cell Cardiol. 2020, $139,14-23$. [CrossRef]

18. Sala, L.; Hegyi, B.; Bartolucci, C.; Altomare, C.; Rocchetti, M.; Váczi, K.; Mostacciuolo, G.; Szentandrássy, N.; Severi, S.; Nánási, P.P.; et al. Action potential contour contributes to species differences in repolarization response to $\beta$-adrenergic-stimulation. Europace 2018, 20, 1543-1552. [CrossRef] [PubMed]

19. Szentadrássy, N.; Bányász, T.; Bíró, T.; Szabó, G.; Tóth, I.B.; Magyar, J.; Lázár, J.; Varró, A.; Kovács, L.; Nánási, P.P. Apico-basal inhomogeneity in distribution of ion channels in canine and human ventricular myocardium. Cardiovasc. Res. 2005, 65, 851-860. [CrossRef] 
20. Szabó, G.; Szentandrássy, N.; Bíró, T.; Tóth, I.B.; Czifra, G.; Magyar, J.; Bányász, T.; Varró, A.; Kovács, L.; Nánási, P.P. Asymmetrical distribution of ion channels in canine and human left ventricular wall: Epicardium versus midmyocardium. Pflügers Arch. 2005, 450, 307-316. [CrossRef]

21. Jost, N.; Virág, L.; Comtois, P.; Ördög, B.; Szúts, V.; Seprényi, G.; Bitay, M.; Kohajda, Z.; Koncz, I.; Nagy, N.; et al. Ionic mechanisms limiting cardiac repolarization reserve in humans compared to dogs. J. Physiol. 2013, 591, 4189-4206. [CrossRef] [PubMed]

22. Fülöp, L.; Bányász, T.; Magyar, J.; Szentandrássy, N.; Varró, A.; Nánási, P.P. Reopening of L-type calcium channels in human ventricular myocytes during applied epicardial action potentials. Acta Physiol. Scand. 2004, 180, 39-47. [CrossRef] [PubMed]

23. Jost, N.; Acsai, K.; Horváth, B.; Bányász, T.; Bitay, M.; Bogáts, G.; Nánási, P.P. Contribution of $\mathrm{I}_{\mathrm{Kr}}$ and $\mathrm{I}_{\mathrm{K} 1}$ to ventricular repolarization in canine and human myocytes. Is there any influence of action potential duration? Basic Res. Cardiol. 2009, 104, 33-41. [CrossRef]

24. Bányász, T.; Fülöp, L.; Magyar, J.; Szentandrássy, N.; Varró, A.; Nánási, P.P. Endocardial versus epicardial differences in L-type calcium current in canine ventricular myocytes studied by action potential voltage clamp. Cardiovasc. Res. 2003, 58, 66-75. [CrossRef]

25. Maltsev, V.A.; Silverman, N.; Sabbah, H.N.; Undrovinas, A.I. Chronic heart failure slows late sodium current in human and canine ventricular myocytes: Implications for repolarization variability. Eur. J. Heart Fail 2007, 9, 219-227. [CrossRef] [PubMed]

26. Varró, A.; Tomek, J.; Nagy, N.; Virag, L.; Passini, E.; Rodriguez, B.; Baczkó, I. Cardiac transmembrane ion channels and action potentials: Cellular physiology and arrhythmogenic behavior. Physiol. Rev. 2021, 101, 1083-1176. [CrossRef]

27. Clancy, C.E.; Tateyama, M.; Liu, H.; Wehrens, X.H.; Kass, R.S. Non-equilibrium gating in cardiac sodium cahannels: An original mechanism of arrhythmia. Circulation 2003, 107, 2233-2237. [CrossRef]

28. Fischmeister, R.; DeFelice, L.J.; Ayer, R.K.; Levi, R.; DeHaan, R.L. Channel currents during spontaneous action potentials in embryonic chick heart sells. The action potential patch clamp. Biophys. J. 1984, 46, 267-271. [CrossRef]

29. Nánási, P.P.; Szentandrássy, N.; Tóth, A.; Bányász, T. Power of the action potential voltage clamp technique. In Advances in Cardiomyocyte Research; Nanasi, P., Ed.; Transworld Research Network: Kerala, India, 2010; pp. 93-119.

30. Hegyi, B.; Chen-Izu, Y.; Izu, L.T.; Rajamani, S.; Belardinelli, L.; Bers, D.M.; Bányász, T. Balance between rapid delayed rectifier K ${ }^{+}$ current and late $\mathrm{Na}^{+}$current on ventricular repolarization. An effective antiarrhythmic target? Circ. Arrhythm. Electrophysiol. 2020, 13, e008130. [CrossRef]

31. Hegyi, B.; Bossuyt, J.; Griffiths, L.G.; Shimkunas, R.; Coulibalya, Z.; Jiana, Z.; Grimsrudf, K.N.; Sondergaard, C.S.; Ginsburg, K.S.; Chiamvimonvata, N.; et al. Complex electrophysiological remodeling in postinfarction ischemic heart failure. Proc. Natl. Acad. Sci. USA 2018, 115, E3036-E3044. [CrossRef]

32. Puglisi, J.L.; Yuan, W.; Bassani, J.W.M.; Bers, D.M. Ca ${ }^{2+}$ influx through $\mathrm{Ca}^{2+}$ channels in rabbit ventricular myocytes during action potential clamp: Influence of temperature. Circ. Res. 1999, 85, e7-e16. [CrossRef]

33. Shimoni, Y.; Clark, R.B.; Giles, W.R. Role of an inwardly rectifying potassium current in rabbit ventricular action potential. J. Physiol. 1992, 448, 709-727. [CrossRef] [PubMed]

34. Hegyi, B.; Bányász, T.; Izu, L.T.; Belardinelli, L.; Bers, D.M.; Chen-Izu, Y. $\beta$-adrenergic regulation of late $\mathrm{Na}^{+}$current during cardiac action potential is mediated by both PKA and CaMKII. J. Mol. Cell Cardiol. 2018, 123, 168-179. [CrossRef] [PubMed]

35. Arreola, J.; Dirksen, R.T.; Shieh, R.C.; Williford, D.J.; Sheu, S.S. Ca ${ }^{2+}$ current and $\mathrm{Ca}^{2+}$ transients under action potential clamp in guinea pig ventricular myocytes. Am. J. Physiol. 1991, 261, C393-C397. [CrossRef]

36. Doerr, T.; Dengerm, R.; Doerr, A.; Trautwein, W. Ionic currents contributing to the action potential in single ventricular myocytes of the guinea pig studied with action potential clamp. Pflügers Arch. 1990, 416, 230-237. [CrossRef]

37. Ibarra, J.; Morley, G.E.; Delmar, M. Dynamics of the inward rectifier $\mathrm{K}^{+}$current during the action potential of guinea pig ventricular myocytes. Biophys. J. 1991, 60, 1534-1539. [CrossRef]

38. Rocchetti, M.; Besana, A.; Gurrola, G.B.; Possani, L.D.; Zaza, A. Rate dependency of delayed rectifier currents during the guinea-pig ventricular action potential. J. Physiol. 2001, 534, 721-732. [CrossRef] [PubMed]

39. Banyasz, T.; Horvath, B.; Jian, Z.; Izu, L.T.; Chen-Izu, Y. Profile of L-type $\mathrm{Ca}^{2+}$ current and $\mathrm{Na}^{+} / \mathrm{Ca}^{2+}$ exchange current during the cardiac action potential in ventricular myocytes. Heart Rhythm. 2012, 9, 134-142. [CrossRef]

40. Horvath, B.; Banyasz, T.; Jian, Z.; Hegyi, B.; Kistamas, K.; Nanasi, P.P.; Izu, L.T.; Chen-Izu, Y. Dynamics of the late Na ${ }^{+}$current during cardiac action potential and its contribution to afterdepolarizations. J. Mol. Cell Cardiol. 2013, 64, 59-68. [CrossRef]

41. Zaza, A.; Rocchetti, M.; Brioschi, A.; Cantadori, A.; Ferroni, A. Dynamic $\mathrm{Ca}^{2+}$-induced inward rectification of $\mathrm{K}^{+}$current during the ventricular action potential. Circ. Res. 1998, 82, 947-956. [CrossRef]

42. Bányász, T.; Magyar, J.; Szentandrássy, N.; Horváth, B.; Birinyi, P.; Szentmiklósi, J.; Nánási, P.P. Action potential clamp fingerprints of $\mathrm{K}^{+}$currents in canine cardiomyocytes: Their role in ventricular repolarization. Acta Physiol. Scand. 2007, 190, 189-198. [CrossRef] [PubMed]

43. Murphy, L.; Renodin, D.; Antzelevitch, C.; Di Diego, J.M.; Cordeiro, J.M. Extracellular proton depression of peak and late Na ${ }^{+}$ current in the canine left ventricle. Am. J. Physiol. Heart Circ. Physiol. 2011, 301, H936-H944. [CrossRef] [PubMed]

44. Apkon, M.; Nerbonne, J.M. Characterization of two distinct depolarization-activated $\mathrm{K}^{+}$currents in isolated adult rat ventricular myocytes. J. Gen. Physiol. 1991, 97, 973-1011. [CrossRef] [PubMed]

45. Josephson, I.R.; Sanchez-Chapula, J.; Brown, A.M. Early outward current in rat single ventricular cells. Circ. Res. 1984, 54, 157-162. [CrossRef] 
46. Josephson, I.R.; Sanchez-Chapula, J.; Brown, A.M. A comparison of calcium currents in rat and guinea pig single ventricular cells. Circ. Res. 1984, 54, 144-156. [CrossRef]

47. Benndorf, K.; Nilius, B. Properties of an early outward current in single cells of the mouse ventricle. Gen. Physiol. Biophys. 1988, 7, 449-466.

48. Giles, W.R.; Imaizumi, Y. Comparison of potassium currents in rabbit atrial and ventricular cells. J. Physiol. 1988, 405, 123-145. [CrossRef]

49. Hiraoka, M.; Kawano, S. Calcium-sensitive and insensitive transient outward current in rabbit ventricular myocytes. J. Physiol. 1989, 410, 187-212. [CrossRef]

50. Varró, A.; Nánási, P.P.; Lathrop, D.A. Voltage clamp characteristics of ventricular myocytes in rabbit. Cardioscience 1991, 2, $233-243$. [PubMed]

51. Wang, Z.; Feng, J.; Shi, H.; Pond, A.; Nerbonne, J.M.; Nattel, S. Potential molecular basis of different physiological properties of the transient outward $\mathrm{K}^{+}$current in rabbit and human atrial myocytes. Circ. Res. 1999, 84, 551-561. [CrossRef] [PubMed]

52. Akar, F.G.; Wu, R.C.; Deschenes, I.; Armoundas, A.A.; Piacentino, V., 3rd; Houser, S.R.; Tomaselli, G.F. Phenotypic differences in transient outward $\mathrm{K}^{+}$current of human and canine ventricular myocytes: Insights into molecular composition of ventricular $I_{\text {to }}$. Am. J. Physiol. Heart Circ. Physiol. 2004, 286, H602-H609. [CrossRef]

53. Calloe, K. Doctoral Dissertation: The transient outward potassium current in healthy and diseased hearts. Acta Physiol. 2019, 225 (Suppl. S717), e13225. [CrossRef]

54. Johnson, E.K.; Springer, S.J.; Wang, W.; Dranoff, E.J.; Zhang, Y.; Kanter, E.M.; Yamada, K.A.; Nerbonne, J.M. Differential expression and remodeling of transient outward potassium currents in human left ventricles. Circ. Arrhythm. Electrophysiol. 2018, 11, e005914. [CrossRef]

55. Kukushkin, N.I.; Gainullin, R.Z.; Sosunov, E.A. Transient outward current and rate dependence of action potential duration in rabbit cardiac ventricular muscle. Pflügers Arch. 1983, 399, 87-92. [CrossRef]

56. Szigligeti, P.; Pankucsi, C.; Bányász, T.; Varró, A.; Nánási, P.P. Action potential duration and force-frequency relationship in isolated rabbit, guinea pig and rat cardiac muscle. J. Comp. Physiol. B 1996, 166, 150-155. [CrossRef] [PubMed]

57. árpádffy-Lovas, T.; Baczkó, I.; Baláti, B.; Bitay, M.; Jost, N.; Lengyel, C.; Nagy, N.; Takács, J.; Varró, A.; Virág, L. Electrical restitution and its modifications by antiarrhythmic drugs in undiseased human ventricular muscle. Front. Pharmacol. 2020, 11, 479. [CrossRef]

58. Hume, J.R.; Uehara, A. Ionic basis of the different action potential configurations of single guinea-pig atrial and ventricular myocytes. J. Physiol. 1985, 368, 525-544. [CrossRef] [PubMed]

59. Litovsky, S.H.; Antzelevitch, C. Transient outward current prominent in canine ventricular epicardium but not endocardium. Circ. Res. 1988, 62, 116-126. [CrossRef]

60. Sanguinetti, M.C.; Jurkiewicz, N.K. Two components of cardiac delayed rectifier $\mathrm{K}^{+}$current. Differential sensitivity to block by class III antiarrhythmic agents. J. Gen. Physiol. 1990, 96, 195-215. [CrossRef] [PubMed]

61. Lambrigts, D.; Sachs, D.H.; Cooper, D.K. Discordant organ xenotransplantation in primates: World experience and current status. Transplantation 1998, 66, 547-561. [CrossRef]

62. Li, G.-R.; Du, X.-L.; Siow, Y.L.; Karmin, O.; Tse, H.-F.; Lau, C.-P. Calcium-activated transient outward chloride current and phase 1 repolarization of swine ventricular action potential. Cardiovasc. Res. 2003, 58, 89-98. [CrossRef]

63. Stankovicova, T.; Szilard, M.; De, S.I.; Sipido, K.R. M cells and transmural heterogeneity of action potential configuration in myocytes from the left ventricular wall of the pig heart. Cardiovasc. Res. 2000, 45, 952-960. [CrossRef]

64. Rodriguez-Sinovas, A.; Cinca, J.; Tapias, A.; Armadans, L.; Tresanchez, M.; Soler-Soler, J. Lack of evidence of M-cells in porcine left ventricular myocardium. Cardiovasc. Res. 1997, 33, 307-313. [CrossRef]

65. Horváth, B.; Kiss, D.; Dienes, C.; Hézső, T.; Kovács, Z.; Szentandrássy, N.; Almássy, J.; Magyar, J.; Bányász, T.; Nánási, P.P. Ion current profiles in canine ventricular myocytes obtained by the "onion peeling" technique. J. Mol. Cell Cardiol. 2021, 158, 153-162. [CrossRef] [PubMed]

66. Zygmunt, A.C.; Robitelle, D.C.; Eddlestone, G.T. $\mathrm{I}_{\mathrm{to1}}$ dictates behavior of $\mathrm{I}_{\mathrm{Cl}(\mathrm{Ca})}$ during early repolarization of canine ventricle. Am. J. Physiol. 1997, 273, H1096-H1106. [CrossRef]

67. Mukherjee, R.; Hewett, K.W.; Walker, J.D.; Basler, C.G.; Spinale, F.G. Changes in L-type calcium channel abundance and function during the transition to pacing-induced congestive heart failure. Cardiovasc. Res. 1998, 37, 432-444. [CrossRef]

68. Antzelevitch, C.; Sicouri, S.; Litovsky, S.H.; Lukas, A.; Krishnan, S.C.; Di Diego, J.M.; Gintant, G.A.; Liu, D.W. Heterogeneity within the ventricular wall. Electrophysiology and pharmacology of epicardial, endocardial, and M cells. Circ. Res. 1991, 69, 1427-1449. [CrossRef]

69. Näbauer, M.; Beuckelmann, D.J.; Uberfuhr, P.; Steinbeck, G. Regional differences in current density and rate-dependent properties of the transient outward current in subepicardial and subendocardial myocytes of human left ventricle. Circulation 1996, 93, 168-177. [CrossRef]

70. Liu, D.W.; Gintant, G.A.; Antzelevitch, C. Ionic bases for electrophysiological distinctions among epicardial, midmyocardial, and endocardial myocytes from the free wall of the canine left ventricle. Circ. Res. 1993, 72, 671-687. [CrossRef] [PubMed]

71. Drouin, E.; Charpentier, F.; Gauthier, C.; Laurent, K.; Le Marec, H. Electrophysiologic characteristics of cells spanning the left ventricular wall of human heart: Evidence for the presence of M cells. J. Am. Coll. Cardiol. 1995, 26, 185-192. [CrossRef] 
72. Li, G.-R.; Lau, C.-P.; Ducharme, A.; Tardif, J.-C.; Nattel, S. Transmural action potential and ionic current remodeling in ventricles of failing canine hearts. Am. J. Physiol. Heart Circ. Physiol. 2002, 283, H1031-H1041. [CrossRef]

73. Wettwer, E.; Amos, G.J.; Posival, H.; Ravens, U. Transient outward current in human ventricular myocytes of subepicardial and subendocardial origin. Circ. Res. 1994, 75, 473-482. [CrossRef]

74. Li, G.-R.; Feng, J.; Yue, L.; Carrier, M. Transmural heterogeneity of action potentials and $\mathrm{I}_{\mathrm{to} 1}$ in myocytes isolated from the human right ventricle. Am. J. Physiol. 1998, 275, H369-H377. [PubMed]

75. Niwa, N.; Nerbonne, J.M. Molecular determinants of cardiac transient outward potassium current $\left(\mathrm{I}_{\mathrm{to}}\right)$ expression and regulation. J. Mol. Cell Cardiol. 2010, 48, 12-25. [CrossRef] [PubMed]

76. Cordeiro, J.M.; Calloe, K.; Moise, N.S.; Kornreich, B.; Giannandrea, D.; Di Diego, J.M.; Olesen, S.P.; Antzelevitch, C. Physiological consequences of transient outward $\mathrm{K}^{+}$current activation during heart failure in the canine left ventricle. J. Mol. Cell Cardiol. 2012, 52, 1291-1298. [CrossRef] [PubMed]

77. Rosati, B.; Grau, F.; Rodriguez, S.; Li, H.; Nerbonne, J.M.; McKinnon, D. Concordant expression of KChIP2 mRNA, protein and transient outward current throughout the canine ventricle. J. Physiol. 2003, 548, 815-822. [CrossRef]

78. Virág, L.; Jost, N.; Papp, R.; Koncz, I.; Kristóf, A.; Kohajda, Z.; Harmati, G.; Carbonell-Pascual, B.; Ferrero, J.M., Jr.; Papp, J.G.; et al. Analysis of the contribution of $\mathrm{I}_{\text {to }}$ to repolarization in canine ventricular myocardium. Br. J. Pharmacol. 2011, 164, 93-105. [CrossRef] [PubMed]

79. Maltsev, V.A.; Sabbah, H.N.; Higgins, R.S.D.; Silverman, N.; Lesch, M.; Undrovinas, A.I. Novel, ultraslow inactivating sodium current in human ventricular cardiomyocytes. Circulation 1998, 98, 2545-2552. [CrossRef]

80. Varró, A.; Baláti, B.; Iost, N.; Takács, J.; Virág, L.; Lathrop, D.A.; Lengyel, C.; Tálosi, L.; Papp, J.G. The role of the delayed rectifier component $\mathrm{I}_{\mathrm{Ks}}$ in dog ventricular muscle and Purkinje fibre repolarization. J. Physiol. 2000, 523, 67-81. [CrossRef] [PubMed]

81. Lost, N.; Virag, L.; Opincariu, M.; Szecsi, J.; Varro, A.; Papp, J.G. Delayed rectifier potassium current in undiseased human ventricular myocardium. Cardiovasc. Res. 1998, 40, 508-515.

82. Stengl, M.; Volders, P.G.A.; Thomsen, M.B.; Spätjens, R.L.H.M.G.; Sipido, K.R.; Vos, M.A. Accumulation of slowly activating delayed rectifier potassium current $\left(\mathrm{I}_{\mathrm{Ks}}\right)$ in canine ventricular myocytes. J. Physiol. 2003, 551, 777-786. [CrossRef]

83. Volders, P.G.A.; Stengl, M.; van Opstal, J.M.; Gerlach, U.; Spätjens, R.L.H.M.G.; Beekman, J.D.M.; Sipido, K.R.; Vos, M.A. Probing the contribution of $\mathrm{I}_{\mathrm{Ks}}$ to canine ventricular repolarization. Key role for $\beta$-adrenergic receptor stimulation. Circulation 2003, 107, 2753-2760. [CrossRef] [PubMed]

84. Imredy, J.P.; Penniman, J.R.; Dech, S.J.; Irving, W.D.; Salata, J.J. Modeling of the adrenergic response of the human I $\mathrm{Ks}_{\mathrm{s}}$ current (hKCNQ1/hKCNE1) stably expressed in HEK-293 cells. Am. J. Physiol. Heart Circ. Physiol. 2008, 295, H1867-H1881. [CrossRef] 